\title{
FAKTOR PENGARUH KEPUASAN KONSUMEN BUSANA MUSLIMAH DI ONLINE SHOP
}

\author{
Widyarini \\ UIN Sunan Kalijaga Yogyakarta \\ widyarini.uin@gmail.com
}

\begin{abstract}
This research objective is to know the influence of products, prices, services and advertising on purchasing satisfaction on Moslem's fashions on the online shop with the decision to buy as a moderating variable. The requirements to become a respondent is at least ever make a purchase on the moslem's fashions online shop. The number of respondents as many as 127 people, taken by convenience sampling method, and the respondents fill out questionnaires via the web. The results showed that advertisement and product have a positive strong significant impact and service has a positive moderate significant impact to the decision to buy. Whereas prices and trust have no effect at all. The study also proves that the decision to buy was able to give satisfaction to the buyer.
\end{abstract}

Keywords: Product, Price, Service, Advertising, Purchasing Satisfaction

\begin{abstract}
PENDAHULUAN
Kaum muslimat diwajibkan untuk mengenakan busana muslim. Pada saat ini perkembangan kesadaran kaum muslim untuk menggunakan busana muslim semakin meningkat secara signifikan, kondisi ini diikuti dengan perkembangan mode pakaian yang semakin bervariasi. Busana muslim yang dimaksudkan di dalam uraian berikut ini dikhususkan pada busana untuk kaum wanita (busana muslimah). Busana selain berfungsi sebagai penutup badan, menjaga kesehatan, memperindah penampilan juga merupakan cerminan status sosial seseorang. Di dalam Islam busana muslim lebih menekankan pada arti menutup aurat, baik untuk kaum lakilaki maupun wanita. Allah memerintahkan umatnya (wanita) untuk mengenakan busana muslimah, yang tercermin pada QS Al-Azhab: 59 yang berbunyi:
\end{abstract}

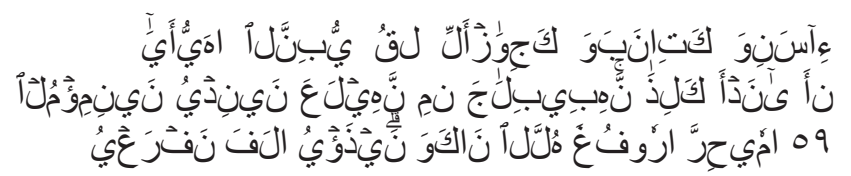

Di dalam ayat tersebut menunjukkan perintah untuk mengenakan busana muslimah, yang merupakan salah satu usaha mempertahankan kehormatannya. Kata jilbab sering dimaknai berbeda, karena di dalam ayat tersebut tidak secara mutlak menyebutkannya. Di dalam QS. An-Nuur: 31 menguatkan perintah tersebut, yang bunyinya:

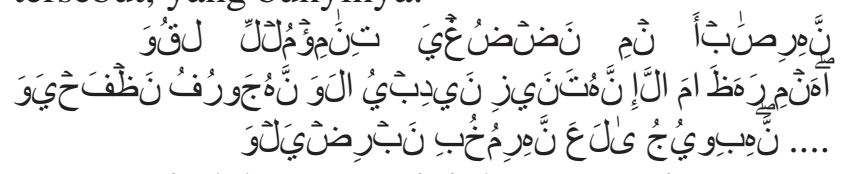

Di dalam ayat ini kaum wanita secara tegas diperintahkan untuk menjaga kehormatan dengan cara menutup aurat terhadap orang-orang yang tidak boleh melihatnya dan semua perhiasan yang ia kenakan. Sehingga kedua ayat tersebut pada hakekatnya bermaksud untuk memelihara 
kesucian dan kehormatan kaum wanita, agar dapat hidup dengan tenteram.

Pakar tafsir al-Biqa'i dalam Shihab (2006) menyebut beberapa pendapat tentang makna jilbab antara lain baju longgar atau kerudung penutup kepala wanita, atau pakaian yang menutupi baju dan kerudung, atau semua pakaian penutup badan wanita. Busana muslimah dapat menunjukkan karakter pemakainya termasuk ke dalam tingkatan ekonomi dan status sosial ekonomi tertentu. Di sisi lain busana akan menunjukkan selera seseorang terhadap mode serta kualitas moralnya. Seiring dengan lajunya perkembangan jaman, mode busana muslimah terus meningkat dari taraf sangat sederhana hingga ke tingkat yang paling sempurna. Dampak dari semakin meningkatnya pemakai busana muslimah, ternyata memberi peluang kepada para pebisnis untuk memanfaatkan peluang tersebut. Perkembangan retail (toko pengecer) busana muslim mampu berkembang pesat. Persaingan antar para penjual busana muslimpun semakin ketat. Toko busana muslim dengan ukuran kecil maupun besar banyak didirikan di berbagai pelosok daerah. Toko busana muslim disambut baik kehadirannya oleh para muslimat.

Ketatnya persaingan toko busana muslim juga mampu membuka peluang pebisnis yang tidak memiliki tempat dengan lokasi strategis. Mereka dapat memanfaatkan perkembangan kecanggihan teknologi, yaitu melakukan penjualan online atau disebut dengan onlineshop. Onlineshop dipandang jauh lebih praktis dibandingkan dengan membuka toko biasa. Selain biaya operasinya lebih murah karena hanya melibatkan sedikit karyawan, juga mendatangkan kepraktisan bagi calon pembelinya. Selain itu, harganya sudah pasti atau bila bisa ditawar, pengurangan harganya tidak banyak. Harga yang sudah pasti, lebih memotivasi calon pembeli untuk melakukan transaksi dibandingkan dengan proses tawar menawar.
Onlineshop merupakan penjualan melalui dunia maya, sehingga calon pembeli hanya mengetahui ciri-ciri dari baju, ukuran, jenis bahan, warna, serta penjelasan berbagai hal tentang baju yang ditawarkan. Penawaran barang melalui dunia maya, tidak terlihat secara kasad mata, namun calon pembeli sudah bisa memprakirakan atau memiliki bayangan seperti apa barang tersebut, serta memprakirakan kemungkinan cocok atau tidaknya. Tentunya dengan prakiraan tersebut penjualan secara online tidak bisa dikatakan 'membeli kucing di dalam karung' yang diistilahkan dengan gharar. Permasalahan akan muncul, bila calon pembeli tidak mengetahui berbagai jenis bahan busana. Untuk memastikan apakah bahan tersebut cocok, maka solusinya adalah calon pembeli mencoba mencari tahu ke toko tekstil guna mendapatkan gambaran tentang kualitas kain busana muslimah tersebut.

Proses pembelian melalui onlineshop berbeda dengan transaksi jual beli seperti pembelian di toko. Setelah menentukan pilihan (model, ukuran, warna dan harga), maka untuk mendapatkan busana tersebut pembeli harus melakukan pembayaran secara transfer. Setelah uang tersebut diterima oleh penjual, maka barang segera dikirim ke pembeli. Proses ini rawan terhadap resiko penipuan, karena pembeli hanya mengetahui nomor tilpon penjual, tidak selalu mengetahui secara pasti lokasi penjual online tersebut. Calon pembeli harus berhati-hati serta banyak mencari informasi dari testimoni para pembeli melalui jejaring ataupun sumber lain. Atas dasar uraian tersebut menunjukkan bahwa, tingkat kepercayaan dari calon pembeli terhadap penjual harus ada. Tingkat kebohongan tidak bisa dideteksi hanya berdasarkan acuan penawaran harga barang yang sangat murah ataupun sangat mahal.

Penawaran produk melalui onlineshop memberi kemudahan calon pembeli untuk melakukan pemilihan, baik model, warna 
ataupun kualitas bahan, tanpa ada rasa 'sungkan' dilihat atau ditunggui oleh penjual. Pemilihan dilakukan tidak di lokasi toko, namun melalui gambar iklan. Calon pembeli memiliki kebebasan waktu dan tempat dalam memilih barang karena bisa dilakukan kapan saja dan dimana saja. Jika keputusan sudah diambil, baru menghubungi penjual secara online. Demikian juga tentang harga busana, calon pembeli bisa mempertimbangkan murah atau mahal serta kecocokkan dengan jumlah dananya.

Model pelayanan onlineshop sangat terbatas, namun memiliki pengaruh dalam pertimbangan keputusan beli maupun kepuasan yang akan diterima oleh calon pembeli. Pelayanan diberikan melalui dunia maya berupa komunikasi melalui internet, namun kadang bisa dilayani melalui telepon. Pada umumnya penyampaian informasi cukup lengkap, sehingga meminimumkan pertanyaan tentang karakteristik barang dagangan maupun tawar menawar harga. Pelayanan penjualan busana muslim lebih condong pada proses pengiriman barang yang sudah dibeli. Pengertian proses adalah kecepatan barang sampai pada tujuan, sehingga penjual harus pandai-pandai memilih mitra kerja untuk pengiriman barang, agar secepatnya pengiriman bisa sampai ke tujuan.

Kegiatan periklanan harus dilakukan oleh setiap pebisnis online, agar pasar potensialnya mengetahui berbagai penawaran barangnya. Iklan melalui online pada umumnya berupa gambar penawaran semua model busana muslim, disertai informasi warna, jenis bahan dan ukuran baju. Gambar jelas disertai bukti kepemilikkan, serta produk tampak indah, disertai kekhasan (keunikan) dari busana, agar bisa memotivasi terjadinya pembelian. Word of mouth tentang pembelian secara online dilakukan oleh para pembeli disampaikan ke teman, saudara ataupun orang yang tidak dikenal. Untuk orang yang tidak dikenal dengan cara penyampaian berita pengalaman pembelian (testimoni) melalui jejaring sosial. Penyebar luasan komunikasi positif yang diterima oleh calon pembeli akan memotivasi terjadinya pembelian.

Atas dasar uraian tersebut di atas terlihat bahwa variabel produk, harga, pelayanan, tingkat kepercayaan dan periklanan dapat berpengaruh terhadap pengambilan keputusan beli. Dampak keputusan beli akan dirasakan oleh pembeli dalam berbagai tingkatan kepuasan.

Tujuan penelitian ini untuk mengetahui faktor pengaruh tingkat kepuasan responden setelah melakukan pembelian busana muslimah melalui online. Responden diperoleh melalui online ataupun jejaring sosial lainnya dengan harapan dapat diperoleh responden dari berbagai daerah. Penyebaran kuesioner melalui internet, memiliki kecenderungan responden menjawab secara jujur, karena mereka dengan senang hati bersedia menjawab kuesioner dalam rangka kegiatan yang bersifat ilmiah.

Penelitian ini mencoba untuk mengungkap pengaruh variabel produk, harga, pelayanan, tingkat kepercayaan, periklanan terhadap keputusan beli, yang berlanjut pada terjadinya kepuasan dalam rangka pembentukan pelanggan. Harapan penjual adalah membentuk pelanggan yang berujung pada loyalitas. Dengan mengetahui pengaruh tingkat kepuasan konsumen setelah berbelanja busana muslimah di onlineshop, maka pebisnis lain bisa menggunakan acuan variabel signifikan untuk penentuan kebijakannya dalam usaha yang sama.

\section{REVIEW LITERATUR DAN HIPOTESIS}

Keputusan beli konsumen dipengaruhi oleh banyak faktor, yang secara umum bisa dikelompokkan menjadi dua, yaitu faktor internal dan eksternal. Faktor internalnya antara lain: faktor psikologis (persepsi, motivasi, sikap dan tingkat kepercayaan). Persepsi terhadap barang sangat beragam meskipun penilaian dilakukan terhadap barang yang sama. Hal ini terjadi karena 
banyak penyebab, antara lain: perbedaan selera, lingkungan, pendidikan, kelas sosial maupun budaya. Persepsi merupakan salah satu faktor penentu pengambilan keputusan bagi konsumen. Motivasi pada diri seseorang merupakan salah satu faktor pemicu terjadinya pembelian busana muslimah melalui online. Motivasi bisa berasal dari dalam diri ataupun dari luar diri seseorang. Motivasi dari dalam diri dapat berupa kemampuan menggunakan internet, memiliki wawasan tentang cara pembelian melalui internet, keyakinan bahwa penjual dapat dipercaya. Motivasi dari luar dapat berupa iklan, testimoni ataupun word of mouth. Sikap adalah tindakan akhir setelah mempertimbangkan banyak hal. Sikap tersebut ditunjukkan dalam bentuk pengambilan keputusan yaitu membeli ataupun tidak membeli. Konsekuensi dari keputusan beli adalah perilaku paska pembelian yaitu puas ataupun tidak puas. Kepuasan pada dasarnya terdiri atas beberapa tingkatan mulai dari sangat puas sampai dengan sangat tidak puas. Jika kenyataan melebihi harapan, maka pembeli akan merasa sangat puas. Demikian pula sebaliknya, jika kenyataan yang didapat tidak sesuai dengan harapan, dikatakan sangat tidak puas (Kotler dan Keller, 2009). Untuk mengetahui kepuasan tersebut, persyaratan responden adalah: pernah melakukan pembelian busana muslimah melalui online. Wanita dewasa dengan harapan membeli busana muslim untuk dipakai sendiri (asumsi pembeli = pemakai). Tingkat kepuasan inilah yang harus diketahui oleh penjual, sebagai dasar strategi kebijakan selanjutnya. Tingkat kepuasan merupakan dasar bagi konsumen untuk bersedia menjadi pelanggan atau tidak. Penjual akan berusaha mengubah pembeli menjadi pelanggan dengan pemberian pelayanan terbaiknya. Pelanggan akan melakukan pembelian berulang serta mungkin loyal terhadap produk merk tertentu atau tempat pembeliannya. Melalui word of mouth (WOM) positif ataupun testimoni dari pelanggan, maka akan terbentuk pelanggan-pelanggan baru. Ishak (2012) di dalam penelitiannya menyimpulkan bahwa kepuasan pelanggan mendorong terciptanya Komitmen dan Komunikasi WOM. Komunikasi WOM tidak hanya dipengaruhi oleh kepuasan, tetapi juga dipengaruhi oleh komitmen.

Faktor eksternal yang berpengaruh terhadap pengambilan keputusan beli antara lain: produk, harga, pelayanan dan periklanan. Produk dalam pengertian umum merupakan semua barang atau jasa yang ditawarkan kepada calon pembeli. Di dalam penelitian ini produk adalah barang (berujud), namun konsumen belum melihat secara langsung ujud fisiknya. Penilaian terhadap barang hanya bisa dilihat melalui gambar dan informasi karakteristik busana muslimah yang diberikan oleh pihak penjual.

Pengertian harga pada pembelian produk melalui online adalah sejumlah uang untuk mendapatkan busana muslimah. Pembeli akan mempertimbangkan kualitas kain, model (keunikan), resiko tidak cocok ukuran, kecepatan pengiriman barang sampai pada pembeli ataupun hal lain. Hal ini perlu dilakukan karena pembelian tidak secara langsung melihat fisik busana muslimah, namun hanya mengetahui karakteristik barangnya. Di dalam pembelian secara oline dimungkinkan terjadinya perbedaan antara harapan dengan kenyataan, sebagai akibat dari tampilannya terlihat bagus karena keahlian dalam pemotretan. Demikian juga halnya dengan kualitas kain maupun warna.

Pelayanan adalah berbagai tindakan dari penjual terhadap pembeli, melalui sikap keramahan, pemenuhan ketepatan atas janji penjual (misal: kualitas barang, ketepatan waktu pengiriman, penjelasan kriteria barang secara jujur). Keramahan dimaksud bisa berupa komunikasi melalui telepon antara penjual dengan pembeli ataupun bahasa tulis di dalam berkomunikasi melalui media internet.

Periklanan adalah usaha penjual untuk memberitahukan, memperkenalkan, membujuk ataupun meyakinkan calon pembeli agar 
bersedia melakukan pembelian. Periklanan bisa dilakukan dengan berbagai cara, dalam penelitian ini dilakukan melalui media internet. Penjual memasang gambar atau foto busana muslimah yang akan dijual, dengan memberikan informasi ukuran, jenis bahan ataupun berbagai informasi lain sesuai dengan model busana muslimah. Dari gambar-gambar tersebut diharapkan calon pembeli bisa mendapatkan gambaran secara jelas dan utuh tentang busana muslimah yang ditawarkan.

Transaksi pembelian akan dilakukan melalui internet, barang akan dikirim secepatnya setelah uang pembayaran ditransfer melalui bank dan uang tersebut sudah diterima oleh penjual. Tentunya setelah pembeli menerima barang, baru dapat mengetahui kecocokan antara 'janji' penjual dengan kenyataan. Konsekuensi logis dari proses jual beli model ini adalah adanya kepercayaan dari pembeli terhadap penjual. Hal ini sangat penting bagi pembeli, agar tidak ditipu oleh penjual, mengingat kejahatan melalui online sering terjadi. Untuk itu tingkat kehati-hatian calon pembeli terhadap penjualan melalui online harus dilakukan. Banyak cara dapat dilakukan oleh calon pembeli sebelum melakukan pengambilan keputusan, antara lain: bertanya ke teman yang pernah melakukan pembelian melalui onlineshop, testimoni dari para pembeli di online tersebut, menanyakan ke lembaga penjamin transaksi melalui online ataupun melakukan kontrol alamat atau tempat penjual apabila dalam satu kota dan mudah dijangkau. Hal ini mungkin dilakukan, karena beberapa penjual melalui online memiliki toko dengan alamat dan nama jelas sebagai pusat penjualannya.

Penjualan melalui onlineshop terjadi setelah masyarakat sudah banyak mengenal dan menggunakan internet. Ide ini tentu saja sangat menarik, sebagai alternatif pilihan cara beli dengan jangkauan luas tetapi praktis. Dikatakan demikian, karena menyingkat waktu (tidak perlu pergi ke toko), pemilihan barang bisa dilakukan dimana saja dan kapan saja, selama handphone (laptopnya) memiliki fasilitas internet. Bisa berpikir berlama-lama di rumah, tidak perlu malu terhadap penjualnya, bahkanbisamembandingkan model, harga ataupun hal lain yang dipandang perlu. Kelemahannya adalah calon pembeli tidak bisa mencoba busana muslimah tersebut sebelum barang kiriman sampai di rumah. Dari segi kepantasan saat dipakai pada tubuh calon pembeli tidak dapat diketahui, sebelum busana tersebut dibelinya. Kelemahan lain adalah ukuran (large, medium dan small) kadang tidak standar. Jika hal ini terjadi, maka baju tersebut tentunya akan sangat mengecewakan pembelinya.

Marentek (2013) menunjukkan bahwa waktu dan kepercayaan berpengaruh positif terhadap keputusan beli melalui online, tetapi tidak berpengaruh terhadap kepuasan. Harga, keamanan dan kepercayaan berpengaruh positif signifikan terhadap keputusan beli maupun kepuasan pembelian melalui online yang dimediasi oleh keputusan pembelian.

Produk merupakan poin penting di dalam keputusan beli, terutama untuk busana muslimah, karena akan dipakai untuk menutup tubuh dan membentuk imej tertentu terhadap pemakainya (pembeli). Busana muslimah yang dikenakan oleh mayoritas muslim belum tentu kaffah, namun sudah menunjukkan adanya usaha untuk lebih baik di dalam menjalankan perintah agama Islam.

Penelitian ini ingin membuktikan dugaan pengaruh persepsi produk terhadap keputusan beli konsumen, dengan pernyataan sebagai berikut:

H1: Produk berpengaruh positif terhadap keputusan beli konsumen

Harga suatu produk sangat signifikan dalam pemberian value kepada konsumen dan mempengaruhi imej produk serta keputusan konsumen untuk membeli suatu produk (Lupiyoadi, 2013). Kesan harga mahal menyebabkan konsumen tidak bersedia melakukan pembelian. Hasil penelitian Marentek 
(2013) menunjukkan harga berpengaruh positif signifikan terhadap kepuasan konsumen dalam pembelian melalui online. Berbeda dengan penelitian Marentek (2013) di dalam penelitian ini dikatakan harga berpengaruh negatif signifikan, karena menggunakan acuan secara umum, yakni semakin murah harga busana muslim, maka volume penjualan akan semakin meningkat. Murah dalam pengertian masih terjangkau oleh segmen pasarnya (kelas sosial menengah ke bawah). Untuk itu pernyataan hipotesis menjadi:

$\mathrm{H} 2$ : Harga berpengaruh negatif terhadap keputusan beli konsumen

Pelayanan adalah setiap tindakan penawaran produk oleh perusahaan kepada pihak calon pembeli yang bersifat intangible (Tjiptono, 2008). Pelayanan melalui online dikatakan baik, bila sikap karyawan (penjual), kecepatan melayani, keramahan serta komunikasi melalui internet ataupun telepon dilakukan dengan baik. Dalam penelitian ini pernyataan hipotesis adalah sebagai berikut:

H3: Pelayanan berpengaruh positif terhadap keputusan beli konsumen

Tingkat kepercayaan merupakan komponen dasar dari kegiatan pemasaran dalam menciptakan hubungan dengan calon konsumen ataupun konsumennya. Jika calon konsumen mempercayai pernyataan penjual, maka keputusan beli akan dilakukan. Demikian juga sebaliknya. Di dalam proses pembelian pada onlineshop, kepercayaan merupakan faktor penting dalam pengambilan keputusan beli. Kepercayaan berhubungan dengan pemberian informasi tentang produk yang disampaikan secara akurat dan penjualnyapun harus mampu meyakinkan dengan berbagai cara bahwa keberadaannya (sebagai toko) memang benar-benar ada. Artinya penjual tidak melakukan penipuan, jika pengiriman uang pembelian sudah ditransfer, maka barang segera dikirim. Untuk menanamkan rasa percaya tersebut, bukanlah pekerjaan gampang. Pembentukan imej, testimoni, pihak penanggung jawab (penjual) haruslah jelas serta terukur. Proses jual beli tidak akan terjadi, apabila kepercayaan tidak bisa diciptakan oleh penjual. Untuk itu, pernyataan hipotesis adalah sebagai berikut:

H4: Tingkat Kepercayaan berpengaruh positif terhadap keputusan beli konsumen

Iklan adalah bentuk presentasi dan promosi non pribadi tentang penawaan barang oleh perusahaan melalui media tertentu, yang berlangsung satu arah. Iklan dikatakan menarik, jika mampu memotivasi calon konsumen untuk melakukan pembelian. Penjualan melalui online perlu melakukan komunikasi dengan calon pembeli. Pemberian infomasi secara jelas serta gambar menarik (tidak berbohong) untuk berbagai penawaran produk. Sehingga pernyataan hipotesisnya adalah:

H5: Periklanan berpengaruh positif terhadap keputusan beli konsumen

Penilaian tentang kepuasan konsumen suatu barang sangatlah penting karena dapat digunakan sebagai penentu kebijakan bagi perusahaan. Penilaian kepuasan barang dengan jasa, sangat berbeda. Kepuasan barang tidak harus diawali dari keputusan beli. Kadang hanya dengan melihat (tidak beli) seseorang sudah bisa merasakan kepuasannya. Sementara untuk jasa, tidak bisa merasakan kepuasannya sebelum melakukan pembelian karena tidak berujud. Untuk pembelian barang pada onlineshop, kepuasan baru bisa dirasakan setelah melakukan keputusan beli serta barang diterima. Hal ini terjadi karena pada saat melakukan transaksi pembelian hanya melihat gambar, belum melihat secara fisik barangnya. Apa yang terlihat pada gambar kadang tidak sama dengan kenyataan. Gambar atau foto bisa mengelabui mata para pemerhati. Kepandaian fotografer serta kecanggihan teknologi mampu mengubah barang yang kurang bagus menjadi terlihat bagus ataupun dari sudut pengambilan gambar, sehingga mampu menumbuhkan daya tarik untuk memilikinya. 
Atas dasar uraian tersebut, hipotesisnya adalah sebagai berikut:

H6: Keputusan beli berpengaruh positif terhadap kepuasan konsumen

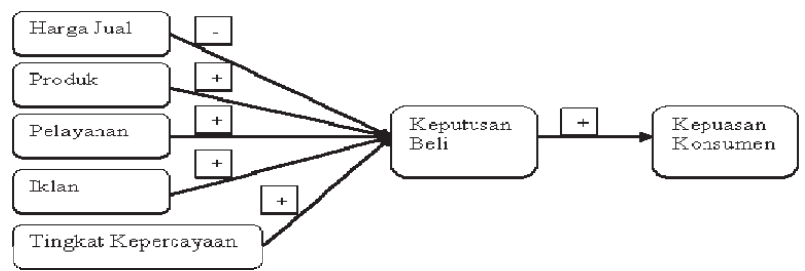

Gambar1

Pola Pikir Faktor Pengaruh Kepuasan Konsumen Busana Muslimah di Onlineshop

\section{METODE PENELITIAN}

\section{Populasi dan Sampel}

Penelitian ini termasuk ke dalam penelitian survey. Populasinya adalah masyarakat yang pernah melakukan pembelian busana muslimah melalui online. Sampel minimal sebanyak 100 responden, dasar acuan rumus Slovin, dengan jumlah populasi tidak terbatas dan tingkat kesalahan $10 \%$. Responden di dalam penelitian ini sebanyak 131 orang, jawaban kuesioner diperoleh selama 3 (tiga) minggu pengumpulan data dimulai awal Mei 2014. Ternyata jumlah data yang memenuhi persyaratan dan dapat digunakan untuk sampel hanya sebanyak 127 responden. Metode pengambilan sampel menggunakan convenience sampling.

\section{Uji Validitas dan Reliabilitas Butir-butir Kuesioner}

Uji validitas dilakukan untuk mengetahui valid atau tidaknya suatu kuesioner. Hasil penelitian dikatakan valid, jika terdapat kesamaan antara data terkumpul dengan data riil yang terjadi pada obyek penelitian. Jawaban kuesioner diukur dengan menggunakan skala Likert, yaitu Sangat Setuju diberi nilai 5 dan
Sangat Tidak Setuju diberi nilai 1. Perhitungan validitas dengan menggunakan teknik korelasi Product Moment. Pertanyaan dinyatakan valid, jika hasil perhitungan korelasi lebih besar dari 0,196. Kuesioner dapat dikatakan reliabel, jika jawaban responden terhadap pertanyaan konsisten dari waktu ke waktu. Perhitungan dengan menggunakan alat uji Cronbach Alpha, dengan menggunakan dasar nilai Alpha lebih dari 0,6 .

Tabel 1

Kisi-kisi Pernyataan, Hasil Uji Validitas dan Reliabilitas

\begin{tabular}{|c|c|c|c|c|c|}
\hline \multirow{2}{*}{$\begin{array}{l}\text { No. } \\
\text { Bu-tir }\end{array}$} & \multicolumn{3}{|c|}{ Hasil Uji Validitas } & \multicolumn{2}{|c|}{ Hasil Uji Reliabilitas } \\
\hline & Kisi-kisi Pernyataan & $\mathrm{r}_{\text {hitumg }}$ & Kesim pulan & $\begin{array}{l}\text { Cronbach } \\
\text { Alpha } \\
\text { hitung }\end{array}$ & Kesimpulan \\
\hline \multicolumn{6}{|c|}{ Harga Jual } \\
\hline HJI & $\begin{array}{l}\text { Harga sebanding dengan } \\
\text { keunikan model }\end{array}$ & 0.723 & Valid & \multirow{5}{*}{0.664} & \multirow{5}{*}{ Reliabel } \\
\hline HJ2 & Lebih murah dari toko biasa & 0.741 & Valid & & \\
\hline HJ3 & $\begin{array}{l}\text { Mendapat potongan harga, jika } \\
\text { membeli beberapa buah baju }\end{array}$ & 0.773 & Valid & & \\
\hline HJ4 & $\begin{array}{l}\text { Harga produk sesuai dengan } \\
\text { kesan kualitas }\end{array}$ & 0.769 & Valid & & \\
\hline HJ5 & Harga bisa ditawar & 0.824 & Valid & & \\
\hline \multicolumn{6}{|c|}{ Produk } \\
\hline $\operatorname{Prl}$ & Produk sesuai dengan selera & 0.750 & Valid & \multirow{6}{*}{0.784} & \multirow{6}{*}{ Reliabel } \\
\hline $\operatorname{Pr} 2$ & $\begin{array}{l}\text { Produk sesuai dengan mode } \\
\text { (modis) }\end{array}$ & 0.834 & Valid & & \\
\hline $\operatorname{Pr} 3$ & $\begin{array}{l}\text { Produk sesuai dengan syariat } \\
\text { islam }(\mathrm{kaffah})\end{array}$ & 0.678 & Valid & & \\
\hline $\operatorname{Pr} 4$ & Modelnya unik & 0.784 & Valid & & \\
\hline $\operatorname{Pr} 5$ & $\begin{array}{l}\text { Produk yang ditawarkan tersedia } \\
\text { dalam beberapa warna }\end{array}$ & 0.743 & Valid & & \\
\hline $\operatorname{Pr} 6$ & Produknya selalu ready stock & 0.742 & Valid & & \\
\hline \multicolumn{6}{|c|}{ Pelayanan } \\
\hline$P l 1$ & Respon kepada pembeli cepat & 0.711 & Valid & \multirow{5}{*}{0.619} & \multirow{5}{*}{ Reliabel } \\
\hline$P l 2$ & $\begin{array}{l}\text { Penjual selalu memberikan } \\
\text { update info terbaru }\end{array}$ & 0.666 & Valid & & \\
\hline$P l 3$ & $\begin{array}{l}\text { Packing/pengemasan produk } \\
\text { bagus }\end{array}$ & 0.583 & Valid & & \\
\hline Pl4 & $\begin{array}{l}\text { Waktu pengiriman sesuai dengan } \\
\text { yang dijanjikan }\end{array}$ & 0.757 & Valid & & \\
\hline Pl5 & $\begin{array}{l}\text { Kenyamanan (bisa dilakukan } \\
\text { di rumah/dimana saja) dalam } \\
\text { memilih }\end{array}$ & 0.601 & Valid & & \\
\hline \multicolumn{6}{|c|}{ Tingkat Kepercayaan } \\
\hline TKI & $\begin{array}{l}\text { Banyaknya testimoni yang baik } \\
\text { mengenai track record dari } \\
\text { peniual }\end{array}$ & 0.711 & Valid & \multirow{5}{*}{0.608} & \multirow{5}{*}{ Reliabel } \\
\hline TK2 & $\begin{array}{l}\text { Banyaknya bukti-bukti transaksi } \\
\text { yang dicantumkan penjual }\end{array}$ & 0.774 & Valid & & \\
\hline TK3 & Yakin atas kualitas bahan & 0.747 & Valid & & \\
\hline TK4 & $\begin{array}{l}\text { Informasi produk sama dengan } \\
\text { kenyataan }\end{array}$ & 0.765 & Valid & & \\
\hline TK5 & $\begin{array}{l}\text { Yakin barang langsung } \\
\text { dikirimkan setelah uang diterima }\end{array}$ & 0.546 & Valid & & \\
\hline
\end{tabular}




\begin{tabular}{|c|c|c|c|c|c|}
\hline \multicolumn{5}{|c|}{ Iklan } & \multirow{6}{*}{ Reliabel } \\
\hline$I \mathrm{kl}$ & Tampilan web iklan menarik & 0.744 & Valid & \multirow{5}{*}{0.656} & \\
\hline$I k 2$ & $\begin{array}{l}\text { Iklan produk tersebut mudah } \\
\text { diakses }\end{array}$ & 0.788 & Valid & & \\
\hline$I k 3$ & $\begin{array}{l}\text { Iklan produk tersebut sering } \\
\text { muncul di situs-situs dunia maya }\end{array}$ & 0.788 & Valid & & \\
\hline$I k 4$ & $\begin{array}{l}\text { Informasi produk yang } \\
\text { ditampilkan pada iklan mudah } \\
\text { dipahami }\end{array}$ & 0.766 & Valid & & \\
\hline$I k 5$ & $\begin{array}{l}\text { Informasi iklan tentang produk } \\
\text { sesuai dengan keinginan }\end{array}$ & 0.728 & Valid & & \\
\hline \multicolumn{6}{|c|}{ Keputusan Beli } \\
\hline KPI & $\begin{array}{l}\text { Kemudahan dalam proses } \\
\text { transaksi jual belinya }\end{array}$ & 0.767 & Valid & \multirow{5}{*}{0.632} & \multirow{5}{*}{ Reliabel } \\
\hline KP2 & $\begin{array}{l}\text { Mencari informasi terlebih } \\
\text { dahulu mengenai latar belakang } \\
\text { peniual }\end{array}$ & 0.823 & Valid & & \\
\hline KP3 & $\begin{array}{l}\text { Bisa membandingkan harga yang } \\
\text { ditawarkan }\end{array}$ & 0.656 & Valid & & \\
\hline KP4 & $\begin{array}{l}\text { Membeli produk busana muslim } \\
\text { di online shop dari penjual yang } \\
\text { memberikan pelayanan terbaik }\end{array}$ & 0.695 & Valid & & \\
\hline KP5 & $\begin{array}{l}\text { Kemudahan transaksi yang } \\
\text { ditawarkan }\end{array}$ & 0.751 & Valid & & \\
\hline \multicolumn{6}{|c|}{ Kepuasan Konsumen } \\
\hline KKI & $\begin{array}{l}\text { Kualitas produk sesuai dengan } \\
\text { harapan }\end{array}$ & 0.872 & Valid & \multirow{5}{*}{0.727} & \multirow{5}{*}{ Reliabel } \\
\hline KK2 & $\begin{array}{l}\text { Warna baju sesuai dengan } \\
\text { tampilan di toko online }\end{array}$ & 0.861 & Valid & & \\
\hline KK3 & $\begin{array}{l}\text { Ukuran baju standar (S, M, L) } \\
\text { sesuai dengan ukuran badan saya }\end{array}$ & 0.853 & Valid & & \\
\hline KK 4 & $\begin{array}{l}\text { Dengan kualitas bahan tersebut } \\
\text { harganya murah }\end{array}$ & 0.858 & Valid & & \\
\hline KK5 & Proses pengiriman barang cepat & 0.793 & Valid & & \\
\hline
\end{tabular}

Sumber: hasil olah data

Tujuan dari penelitian ini bukan untuk memprediksi nilai dependen variabel (kepuasan beli melalui online), akan tetapi bertujuan untuk mengetahui peran variabel independen terhadap variabel dependen. Gujarati (2004) menyatakan bahwa asumsi normalitas $u_{i}$ tidak esensial jika tujuan penelitian hanya untuk mengetahui peran variabel independen. Estimator OLS adalah BLUE terlepas apakah $u_{i}$ terdistribusi normal atau tidak. "This assumption is not essential if our objective is estimation only. ...the OLS estimators are BLUE regardless of whether the $u_{i}$ are normally distributed or not". Jadi penelitian ini hanya untuk mengetahui kondisi sesaat (potret) pada saat dilakukan penelitian. Dengan demikian uji normalitas tidak dilakukan dalam penelitian ini.

\section{Tabel 2}

\section{Hasil Uji Multikoliniaritas}

\begin{tabular}{|l|r|r|}
\hline \multirow{2}{*}{ Model } & \multicolumn{2}{|c|}{ Collinearity Statistics } \\
\cline { 2 - 3 } & Tolerance & VIF \\
\hline Harga Jual & .271 & 3.687 \\
\hline Produk & .295 & 3.395 \\
\hline Pelayanan & .409 & 2.444 \\
\hline Tngkt Kepercayaan & .410 & 2.439 \\
\hline Iklan & .344 & 2.910 \\
\hline \multicolumn{2}{|c|}{ Variabel Dependen: Keputusan Pembelian } \\
\hline
\end{tabular}

Sumber: hasil olah data
Hasil uji Multikolinieritas dan Heteroskedatistas menunjukkan lolos uji

Tabel 3

Hasil Perhitungan Uji F dan Uji t

\begin{tabular}{|l|r|r|c|l|}
\hline \multicolumn{1}{|c|}{ Keterangan } & Koefisien & t / F hitung & Sig. & \multicolumn{1}{c|}{ Simpulan } \\
\hline Constant) & .817 & 2.935 & .004 & Signifikan kuat \\
\hline Harga jual & .016 & .182 & .856 & Tidak Signifikan \\
\hline Produk & .291 & 2.774 & .006 & Signifikan kuat \\
\hline Pelayanan & .256 & 2.546 & .012 & Signifikan \\
\hline Tingkat Kepercayaan & -.077 & -.880 & .380 & Tidak Signifikan \\
\hline Iklan & .361 & 4.025 & .000 & Signifikan kuat \\
\hline F Hitung & & 36.979 & .000 & Signifikan kuat \\
\hline
\end{tabular}

Sumber: hasil olah data

Panel a. Model I, Variabel Dependen: Keputusan Beli

\begin{tabular}{|l|r|r|c|l|}
\hline \multicolumn{1}{|c|}{ Keterangan } & Koefisien & t / F hitung & Sig. & Simpulan \\
\hline Constant) & -.146 & -.375 & .708 & Tidak Signifikan \\
\hline Keputusan Beli & .911 & 9.621 & .000 & Signifikan kuat \\
\hline F Hitung & & 92.566 & .000 & Signifikan kuat \\
\hline
\end{tabular}

Sumber: hasil olah data

Panel b. Model II, Variabel Dependen: Kepuasan Konsumen

\section{HASIL PENELITIAN DAN PEMBAHASAN}

Responden di dalam penelitian ini mayoritas adalah remaja ataupun wanita dewasa (usia 17-30 tahun). Responden termasuk ke dalam kelompok masyarakat yang berusia produktif, sehingga kegiatannya cukup banyak serta memerlukan busana muslimah dalam jumlah banyak pula guna mendukung penampilannya. Responden termasuk ke dalam kelas sosial menengah ke bawah (51,98\%). Indikator kelas sosial didasarkan pada penghasilan per bulan, status masih mendapat bantuan uang saku dari orang tuanya, serta harga rata-rata busana muslimah yang biasanya dibeli oleh responden yaitu kurang dari Rp 150.000,-. Lokasi tempat tinggal responden dari berbagai provinsi, antara lain: Yogyakarta $(33,07 \%)$, Jawa Tengah $(51,95 \%)$, sisanya dari berbagai daerah dengan prosentase relatif rendah. Responden sudah melakukan pembelian melalui online shop lebih dari dua kali sebanyak 59,05\%, artinya responden sudah memiliki pengalaman berbelanja di onlineshop. Pengalaman responden 
dalam melakukan pembelian melalui online, akan berpengaruh terhadap keputusan beli selanjutnya. Reponden mengetahui onlineshop tempat dilakukannya pembelian atas kemauan sendiri, tidak terpengaruh oleh word of mouth positif dari teman ataupun saudara, namun sebelum melakukan pengambilan keputusan beli responden $(87 \%)$ berusaha mencari banyak informasi tentang toko penjual online yang akan dihubungi. Kondisi ini menunjukkan adanya tingkat kehati-hatian dari responden sebelum melakukan pembelian, untuk meminimalkan terjadinya penipuan.

Uji F untuk Model I maupun Model II menunjukkan bahwa kesalahan kedua model ini sangat kecil (dibawah 1\%), sehingga bisa dikatakan bahwa model sangat baik. Model I memiliki konstanta dengan hasil signifikan kuat, kesimpulannya adalah konstanta model ini berpengaruh kuat terhadap variabel dependen. Model akan dikatakan baik, jika konstanta tidak signifikan, sehingga hanya variabel independen sajalah yang berpengaruh terhadap variabel dependen. Karena model I di dalam penelitian ini menunjukkan konstanta signifikan, maka bisa disimpulkan bahwa terdapat variabel lain yang belum atau tidak dimasukkan ke dalam model, namun memiliki pengaruh kuat terhadap variabel dependen (missing variable). Adanya missing variable merupakan kelemahan dari model penelitian ini, sehingga peneliti berikutnya diharapkan bisa menambah variabel independen lain. Variabel independen lain yang bisa dimasukkan ke dalam model antara lain: kemanan, Word of mouth, desain situs, Search engine dan kategori produk dan nilai (value) produk.

Keamanan berhubungan dengan berbagai informasi yang dibutuhkan oleh responden tentang penjual online (onlineshop), untuk mengurangi kekhawatiran terjadinya penipuan oleh penjual, karena pembeli telah mentransfer uangnya namun belum menerima barangnya. Komunikasi word of mouth merupakan informasi positif maupun negatif dari teman atau saudara tentang onlineshop yang berjualan busana muslim. Word of mouth berbeda dengan testimoni, testimoni yaitu pemberian informasi secara langsung dari nara sumber, biasanya akan dipilih nara sumber yang bisa memberikan informasi positif, supaya penjual online diuntungkan. Word of mouth adalah informasi dari 'mulut ke mulut', tidak selalu berasal dari nara sumber langsung, informasi bisa bersifat positif maupun negatif atas apa yang diketahui baik dari pengalaman sendiri ataupun cerita pengalaman orang lain. Desain situs berhubungan dengan kemudahan untuk diakses dari mana saja (handphone, laptop, tablet), mudah dipahami (hal-hal yang ditampilkan berhubungan dengan informasi), proses pengaksesan cepat. Search engine dan kategori produk dimaksudkan untuk memudahkan calon pembeli mencari produk. Nilai (value) produk berhubungan dengan merk busana muslimah yang sudah dikenal atau disainer/perancang busana muslim tertentu. Di dalam penelitian ini untuk nilai (value) kurang tepat dimasukkan ke dalam model, karena sampel yang diperoleh pada posisi kelas sosial menengah ke bawah. Nilai (value) akan lebih tepat diterapkan untuk responden dengan kelas sosial menengah ke atas.

Konstanta Model II menunjukkan pengaruh yang tidak signifikan, sehingga pada model ini tidak terdapat variabel independen penting yang terlewat. Artinya kepuasan responden baru bisa dirasakan setelah melakukan pembelian. Pada umumnya pembelian barang sudah bisa mengetahui tingkat kepuasannya meskipun belum melakukan pembelian karena barang sudah bisa dilihat, diraba dan mungkin dicoba. Pembelian melalui online hanya bisa dilihat, tidak bisa diraba (meskipun bisa dinilai) dan tidak bisa dicoba sebelum dibeli. Kondisi ini hampir sama dengan karakteristik pembelian jasa. Jasa adalah sesuatu yang tidak berujud, baru bisa merasakan tingkat kepuasannya 
setelah melakukan pembelian. Penilaian atas jasa didasarkan pada bukti fisik yang melingkupinya maupun fasilitas pendukungnya.

Model I menunjukkan hanya ada tiga variabel yang signifikan yaitu: iklan dan produk berpengaruh positif signifikan kuat, sedangkan pelayanan berpengaruh positif signifikan moderat terhadap keputusan beli. Untuk variabel harga dan tingkat kepercayaan tidak berpengaruh signifikan terhadap keputusan beli.

Pembahasan masing-masing adalah sebagai berikut:

\section{Produk}

Produk berpengaruh positif signifikan kuat. Produk di dalam penelitian ini adalah busana muslimah yang dijual di onlineshop. Pada umumnya penawaran busana muslimah melalui online memiliki karakteristik berbeda dengan busana muslimah yang dijual di toko dalam jumlah banyak (barang shopping). Perbedaan tersebut pada keunikkan model dan mungkin jumlah unit produksi untuk model yang sama. Penjualan busana muslimah dengan model sama di toko tertentu, memiliki kecenderungan dibeli oleh pembeli lain yang tinggal dalam satu kota, sehingga si pemakai merasa tidak tampil beda. Pembelian busana muslimah di onlineshop bisa dijangkau dari berbagai kota, sehingga meskipun diproduksi dalam jumlah tertentu pembelinya merasa tampil beda pada saat memakai di kota tempat tinggalnya. Persepsi ini terjadi karena pembeli berasumsi bahwa pembeli busana muslimah dalam kota yang sama kecil kemungkinannya membeli busana muslimah dengan model sama di onlineshop yang sama. Dengan demikian persepsi bisa 'tampil beda' akan terwujud meskipun barangnya bukan barang spesial. Salah satu ciri khas kaum wanita kelas sosial atas adalah membeli busana muslimah yang eksklusif (spesial), harga mahal karena karena desainer hanya membuat satu model busana muslimah untuk satu unit produksi. Kondisi ini sebenarnya juga diharapkan oleh kaum wanita dengan kondisi kelas sosial menengah, yaitu tampil elegan dengan harga terjangkau. Untuk bisa memproduksi hanya satu unit untuk satu model busana muslimah dengan harga terjangkau sangatlah sulit. Solusi yang bisa dilakukan adalah memproduksi dalam jumlah tertentu dijual di berbagai kota, sehingga jumlah unit minimal saja busana tersebut dijual dalam satu kota. Solusi ini bisa terjawab dengan cara penjualan melalui online. Penjual bisa membatasi jumlah unit penjualan untuk setiap kota. Sehingga busana muslimah yang tergolong masuk ke dalam kelompok barang shopping bisa meningkat menjadi barang spesial. Strategi ini bisa diterapkan untuk semua jenis barang shopping dijual melalui online dengan batasan jumlah unit yang dijual melalui online untuk setiap kota pembelian. Tujuannya adalah meningkatkan kepuasan pembeli.

\section{Iklan}

Penjualan busana muslimah melaluionline pada umumnya menyampaikan karakteristik busana muslimah, termasuk penyampaian gambar model, warna, menonjolkan keunikkan asesoris, sehingga iklan memiliki peran penting. Kepandaian di dalam pemasangan gambar melalui web, sehingga terlihat bagus berpengaruh terhadap daya tarik untuk memiliki, yang akan berujung pada keputusan beli. Iklan ditayangkan di beberapa situs dunia maya, sehingga mudah dilihat oleh pengguna internet. Pada umumnya penawaran busana muslimah melalui onlineshop memiliki keunikkan tersendiri, sehingga terlihat tampil beda dan atau mungkin elegant bagi pemakainya. Kepandaian di dalam pemotretan busana muslimah, dimungkinkan berdampak produk terlihat lebih indah dari aslinya. Berbeda dengan pembelian di toko, calon pembeli akan mencari sendiri di gantungan baju yang dipajang dalam jumlah banyak, sehingga keunikan pada busana muslimah tidak terlihat secara langsung. Pencarian model baju diantara banyak baju yang 
digantung kadang membuat orang malas untuk mencari, karena harus melalui proses pengambilan satu per satu dari rak gantungan, memperhatikan model dan komposisi warna, mencoba memantas diri, setelah dirasa cocok mencari ukuran dan tindakan terakhirnya adalah mencoba. Kejadian yang tidak mengenakkan calon pembeli proses pemilihan sudah dilakukan dalam waktu lama ternyata ukuran yang dicari tidak ada (habis). Proses ini kadang harus dilakukan berulang kali sampai dengan mendapatkan busana muslimah yang dirasa cocok. Pembelian melalui online jauh lebih sederhana, meskipun ada resiko ukuran tidak standar dan tidak bisa dicoba terlebih dahulu. Pembelian busana muslimah di onlineshop tidak bisa ditukarkan atau dikembalikan, karena alasan lokasi di luar kota, sehingga biaya kirim harus menjadi perhitungan tersendiri. Biaya kirim bisa termasuk ke dalam penentuan harga jual ataupun ditambahkan pada harga busana muslimah sesuai hasil kesepakatan pada saat transaksi.

Posisi penjualan busana muslimah di onlineshop hampir sama dengan busana muslimah yang dipajang pada etalase toko ataupun pada patung boneka yang diberi baju di dalam toko, sebagai ajang periklanan. Busana muslimah yang dipasang pada boneka memiliki "kelebihan" dibandingkan dengan busana lainnya, untuk memotivasi pengunjung toko agar memperhatikan lebih seksama. Daya tarik dimunculkan melalui warna, motif, asesoris pada busana maupun model busana itu sendiri. Cara ini dipilih dengan harapan mampu mengundang daya tarik bagi calon pembeli yang kebetulan melalui toko tersebut (dipajang di etalasi) ataupun pembeli di dalam toko (boneka berbaju ada di dalam toko). Perbedaannya dengan penjualan di onlineshop calon pembeli tidak bisa merasakan kenyamanan jenis kain busana, namun sudah dipilihkan model yang bagus. Hasil penelitian menunjukkan bahwa iklan berpengaruh positif signifikan kuat.

\section{Pelayanan}

Pelayanan berpengaruh positif signifikan moderat, kondisi ini wajar mengingat pelayanan pembelian melalui onlineshop sangat minim dan tidak semua calon pembeli memanfaatkannya. Pelayanan utama dalam pembelian melalui online adalah ketepatan waktu sampainya barang ke pembeli. Hal ini sangat tergantung pada jasa transportasi pengiriman yang dipilih oleh pihak penjual ataupun atas permintaan pembeli. Terjadinya keterlambatan barang sampai ke pembeli, tidak sepenuhnya tanggung jawab pihak penjual. Ketepatan pemilihan jasa transportasi pengiriman barang adalah tanggung jawab penjual, untuk itu penjual harus berhatihati dalam pemilihannya. Pengiriman barang dalam jangka lama akan mengecewakan pembeli, karena jasa transportasi merupakan salah satu faktor kunci keberhasilan dari penjualan melalui online. Pembeli selalu berharap untuk segera bisa menerima barang yang telah dibayar serta mencoba busana muslimah tersebut. Selain memenuhi keinginan untuk melihat barang aslinya (tidak hanya gambar), pembuktian pantas atau tidak bila busana tersebut dipakai maupun kecukupan dari ukuran baju.

Model II menunjukkan bahwa Keputusan Beli berpengaruh positif signifikan kuat terhadap Kepuasan Konsumen. Pemilihan onlineshop merupakan alternatif tempat pembelian dengan beberapa kemudahan antara lain: bisa melihat gambar produk setiap saat, dimanapun selagi ada jaringan internet. Jika tidak melakukan pembelian karena merasa tidak cocok terhadap harga, maka calon pembeli tidak merasa malu. Efisien waktu karena tidak harus pergi dari rumah dan barang dikirim ke rumah. Pembayaran bisa ditransfer dan bisa dilakukan kapan saja, pada saat melewati ATM ataupun kantor Bank, bahkan mungkin melalui internet banking.

Keputusan beli tidak selalu berakhir dengan kepuasan. Perilaku paska pembelian dimungkinkan beragam yang diawali dengan 
sangat tidak puas sampai dengan sangat puas terhadap beberapa faktor penyebab. Di dalam penelitian ini kepuasan sebagai akibat dari keputusan beli busana muslim ternyata menunjukkan hasil signifikan kuat. Artinya pada saat memutuskan pembelian busana muslimah sudah mempertimbangkan banyak faktor dan mungkin juga memerlukan banyak waktu dalam proses pengambilan keputusannya. Ternyata keputusan tersebut tidak salah, harapan dan kenyataan memberikan hasil yang sebanding, terutama untuk variabel produk, iklan dan pelayanan. Berdasarkan pengalaman konsumen (responden) belum pernah mengalami ditipu dan melakukan pembelian busana muslimah karena senang dengan model maupun warnanya. Pembelian busana muslimah oleh responden sesuai dengan kemampuan dananya.

\section{Tingkat Kepercayaan}

Tingkat kepercayaan diperlukan oleh calon pembeli agar tidak ditipu oleh penjual. Setelah memilih barang, calon pembeli harus mentransfer uang pembelian terlebih dahulu, setelahitu pengiriman barang dilakukan. Transaksi model ini rawan dengan penipuan, karena sangat mungkin setelah uang ditransfer, barang tidak dikirim serta dilakukan penutupan rekening dari penjual. Tingkat kehati-hatian dari calon pembeli harus ada, agar tidak tertipu. Hasil penelitian ini menunjukkan bahwa tingkat kepercayaan tidak berpengaruh signifikan terhadap keputusan beli, otomatis juga tidak berpengaruh signifikan terhadap kepuasan pembeli busana muslimah melalui online. Di dalam penelitian ini responden yang menjadi sampel sudah pernah melakukan pembelian di onlineshop lebih dari dua kali. Atas dasar pengalamannya, responden merasakan proses pembelian berjalan lancar, tidak ada penipuan. Atas dasar pengalaman tersebut, responden merasa bahwa tingkat kepercayaan bisa diabaikan, tentunya untuk bisa mengabaikan tingkat kepercayaan harus ada persyaratan yang mendahuluinya. Beberapa hal yang seharusnya dilakukan oleh calon pembeli melalui online antara lain: Mencari tahu tentang onlineshop tersebut dari testimoni yang berhubungan dengan track record penjual; bukti-bukti transaksi yang dicantumkan oleh penjual, sudah mengenal jenis kualitas bahan, karakteristik busana sinkron dengan gambar/foto busananya dan bila mungkin mencari banyak tahu tentang penjual barangkali memiliki toko dengan alamat jelas, sehingga bisa di cross cek, tidak mencantumkan alamat palsu.

\section{Harga Jual}

Harga merupakan salah satu faktor penentu keputusan beli, karena berhubungan dengan dana dari calon pembeli. Harga dirasa mahal atau tidak terjangkau juga akan berdampak pada pembatalan pembelian. Hasil penelitian ini menunjukkan harga tidak berpengaruh signifikan terhadap keputusan beli. Konsekuensiknya harga tidak berpengaruh terhadap kepuasan beli busana muslimah melalui online. Artinya pembeli mengabaikan besarnya harga jual. Hal ini sangat mungkin terjadi, karena pembeli sudah terlanjur menyukai busana tersebut pada saat melihat gambar iklannya. Rasa senang kadang bisa mengalahkan segalanya, termasuk munculnya emosi dalam keputusan pembelian. Kondisi ini lebih banyak dialami oleh kaum wanita, karena kaum wanita cenderung konsumtif. Masalah utama pada diri pembeli adalah memiliki dana cukup untuk melakukan pembelian atau tidak. Mengacu pada kondisi kelas sosial responden (termasuk kelas sosial menengah ke bawah) dan sudah dewasa, ternyata rata-rata harga busana yang dibeli kurang dari Rp 150.000,-. Atas dasar data tersebut semakin menunjukkan bahwa perilaku beli responden mengabaikaan harga adalah wajar, karena harga busana dengan segala keunikkannya termasuk barang shopping yang tidak mahal. Salah satu indikator pertanyaan adalah harga sebanding dengan keunikkannya, mayoritas $(82 \%)$ responden menyatakan 
persetujuannya. Jika menggunakan indikator pertanyaan harga sesuai dengan kesan kualitas yang ditampilkan responden menjawab setuju hanya $68 \%$. Harga lebih murah dibandingkan harga toko dengan kualitas bahan sama, jawaban responden setuju mencapai 64\%. Kondisi ini menunjukkan bahwa memang benar responden mengabaikan faktor harga karena tertarik dengan keunikkan model. Jika ditelaah lebih dalam ujungnya adalah produk bukan harga.

\section{KESIMPULAN DAN SARAN}

\section{Kesimpulan}

Hasil penelitian ini menunjukkan bahwa kepuasan beli konsumen busana muslimah, dimediasi oleh keputusan beli di onlineshop secara signifikan kuat. Proses keputusan beli konsumen dipengaruhi oleh iklan (signifikan kuat), produk (signifikan kuat) dan pelayanan (signifikan moderat). Tingkat kepercayaan dan harga jual tidak berpengaruh signifikan terhadap keputusan beli busana muslimah melalui online.

\section{Saran}

Model regresi linier I menunjukkan ada missing variable, untuk itu disarankan penelitian selanjutnya menambahkan beberapa variabel independen, misalnya: kemanan, Word of mouth, desain situs, Search engine dan kategori produk dan nilai (value) produk

Di dalam penelitian ini hanya menggunakan 127 responden, untuk peneliti selanjutnya sebaiknya menambah jumlah responden, agar variasi jawaban lebih terlihat.

\section{DAFTAR PUSTAKA}

Engel, F. James, 2012, Perilaku Konsumen, (Terjemahan), jilid I dan 2, Jakarta: Bina Aksara.

Gujarati, Damodar N., 2004, Basic of Econometri, New York: McGraw-Hill Companies.
Hadi, Syamsul dan Widyarini, 2009, Metodologi Penelitian Untuk Manajemen dan Akuntansi, Yogyakarta: Penerbit Ekonisia

Ishak, Asmai, 2012, Analisis Kepuasan Pelanggan Dalam Belanja Online, Sebuah Studi Tentang Penyebab (Antecedents), dan Konsekuensi (Consequents), Jurnal Siasat Bisnis, Vol.16 Juli 2012, Hal 141154.

Kotler, Philip dan Kevin Lane Keller, 2009, Manajemen Pemasaran, (terjemahan), Jakarta: Penerbit Erlangga.

Lovelock, Christopher, Jochen Wirzt and Jacky Mussry, 2011, Pemasaran Jasa, Manusia, Teknologi dan Strategi, Perspektif Indonesia, Jakarta: Penerbit Erlangga

Lupiyoadi, Rambat dan A. Hamdani, 2008, Manajemen Pemasaran Jasa, Jakarta: Salemba Empat

Marentek, Revina Julina, 2013, Pengaruh waktu, Harga, Keamanan dan Kepercayaan Terhadap Kepuasan Pembelian Online yang dimediasi oleh Keputusan Pembelian Online, Jurnal Akuntansi dan Manajemen, Vol 24, No.3, Desember 2013.

Mohammed T Nuseir, dkk., Evidence of Online Shopping: A Consumer Perspective, International Review of Business Research Papers, Vol.6, No,5. Tahun 2010

Sekaran, Uma, 2011, Research Method for Business, (Terjemahan), Jakarta: Penerbit Salemba Empat

Shihab, M. Quraish, 2006, Jilbab, Pakaian Wanita Muslimah, Jakarta: Lentera Hati 
Swastha, Basu, dan T. Hani Handoko, 2012, Manajemen Pemasaran, Analisa Perilaku Konsumen, Yogyakarta: Liberty

Tjiptono, Fandi, 2008, Service Manajemen, Yogyakarta: Penerbit Andi
Yazid, 2001, Pemasaran Jasa, Konsep dan Aplikasi, Yogyakarta: Penerbit Ekonisia Zeitml, Valarie A dan Marie Jo Bitner, 1996, Service Marketing, International Edition: McGraw-Hill 